\title{
Wrestling - et studium i ørkenvandring
}

af Finn Wiedemann

"The Mets, ret så smarte i deres nye frontsnørrede våbenfrakker fra Zhorror, er nu endelig på vej væk fra det fimsede, franske image, der plagede dem hele sidste sæson, mens de var hos Osca Selzer. I går aftes lignede de mere et baseball-hold. Kollektionen var i sin essens $1 \varnothing s$ og romantisk struktureret og kombinerede alvor med vid. Den havde en finish, der var både poleret og fri for billige tricks «. ${ }^{1}$

Uddraget stammer fra Neil Fergusons roman Swish. Swish og beskriver en situation, hvor sportens primære funktion er blevet forvandlet til et spørgsmål om stil og æstetik. Et sciencefictionagtigt billede hvor selve kampens forløb og resultat er blevet gjort til noget absolut sekundært.

Om udviklingen indenfor den traditionelle sport de næste år kommer til at forløbe helt så radikalt, som uddraget fra Fergusons bog ovenover beskriver, er nok tvivlsomt. Men tendensen mod stigende æsteticisme, stilisering og iscenesættelse både inden- og udenfor sportens verden, er i hvert fald uomtvisteligt.

Denne artikel har til hensigt at beskæftige sig med moderne showsport, herunder primært wrestling, set $\mathrm{i}$ et kulturanalytisk perspektiv. Det er artiklens budskab, at wrestling repræsenterer en særlig avanceret form for showsport, en højst ueuropæisk form, der i sig indeholder kritik af den europæiske sport.

Fremgangsmåden vil være den, at der ud fra en analyse af nogle wrestlingkampe foretages en kropskulturel aflæsning af det betydningssystem, der er indeholdt i wrestlingen. Til belysning af dette vil forskellige teorier og synspunkter af henholdsvis Roland Barthes og filosoffen Hans Fink blive inddraget. Derudover vil visse synspunkter af den russiske kulturteoretiker Mikhail Bakhtin blive anvendt med det formål at læse og bestemme wrestlingens krop.

Endelig vil kultursociologen Jean Baudrillard sidst i artiklen blive benyttet $i$ et fors $\varnothing g$ på at perspektivere enkelte af analysens konklusioner i en større kulturel sammenhæng. Dette drejer sig mere konkret om Baudrillards tegnteorier samt synspunkter, der kommer til udtryk i bogen Amerika.

\section{Showsportens succes $i$ efterkrigstiden}

Baggrunden for showsportens fremvækst kan anskues på en lang række måder. For eksempel kan man med Jürgen Habermas tale om »systemverdenens « kolonialisering af »livsverdenen «. Herved forstås en samfundsudvikling, hvor forhold som bureaukratisering, professionalisering og kommer- 
cialisering siden begyndelsen af 1960erne i stigende omfang vokser ind over den enkeltes hverdag og erfaringsverden.

Denne »annektion« medfører, at borgerne mere og mere bliver forvandlet til klienter og forbrugere. Ifølge Habermas kommer underholdningsbranchen og massemedierne derved $\mathrm{i}$ stadig større udstrækning til at udgøre en del af borgernes private forbrug.

Med udgangspunkt i Habermas er dette en af forklaringerne på showsportens succes og stærkt forøgede publikumsinteresse.

En anden måde at anskue dette fænomen ud fra er ved hjælp af den franske filosof Jean François Lyotards begreb om »de store fortællingers« død. Tiden efter 2. verdenskrig er ifølge Lyotard kendetegnet ved, at helheder og sandheder, som det tidligere var muligt at henvise og definere sig i forhold til, smuldrer væk. Forhold der konstituerede det moderne, som eksempelvis ideen om fremskridt, udvikling, troen på årsag og virkning med videre, problematiseres alvorligt.

Frafaldet af de store fortællinger medfører mere konkret, at blandt andet kunst, videnskab og politik ikke længere kan legitimere sig i forhold til disse.

Et lignende mønster kan iagttages indenfor kropskulturen. Kropskulturen var tidligere i vid udstrækning fra og med det moderne (oplysningstiden) forankret $\mathrm{i}$ betydningssystemer udenfor den selv. Fra 1700-tallets slutning og gennem hele 1800-tallet var kroppen et område, som fra statslig side blev gjort til genstand for en civilisationsproces. I slutningen af 1800 -tallet går udviklingen den anden vej, krop- pen bliver da en ting, hvormed den enkelte kan præge sine omgivelser.

Eksempler på dette er gårdmandsgymnastikken, der viste hen til »den gode sags tjeneste « og enkeltmandsidrætten, som fremmede indre karakteregenskaber såsom selvbeherskelse og handlekraft, egenskaber, der kunne karakteriseres som samfundsgavnlige. Et tredie eksempel er Pierre de Coubertins ideer om olympismen. Her var tanken, at olympiaden havde til formål at udøve en gavnlig effekt på verden udenfor.

I disse nævnte eksempler tjener idrætten som middel mod et større mål af ideologisk og moralsk karakter. Dette er ikke længere eller kun i ringe grad tilfældet. I dag tjener idrætten snarere som mål i sig selv.

Dette forhold kan især iagttages indenfor en række nyere idrætsdiscipliner såsom eksempelvis bodybuilding, work out og aerobic, hvor kropsopfattelsen kan siges at være referencel $\varnothing$ s. $^{2}$ Denne såkaldte referenceløse krop kan ligeledes siges at være på spil i showsportsdisciplinen wrestling.

\section{Entreen-med afsat i sport og skuespil}

Som tilskuer til wrestlingkampe er det nødvendigt med en vist kendskab til både andre sportsgrene og teaterverdenen, eftersom en stor del af wrestlingens underholdnings- og fascinationsværdi tager udgangspunkt i elementer hentet fra disse verdener.

Når aktørerne træder ind i den røgfyldte hal, og kameraerne og projekt $\varnothing$ rene rettes imod dem, er dette en scene, der blandt andet kendes fra professionel boksning. Vi har alle set denne 
scene et utal af gange og ved, hvad det betyder - kamp.

Entreen er et ritual, der har til hensigt at præsentere aktørerne for os som mennesker, inden de lukkes ind i arenaen og forvandles til kæmpende. Gennemslusningen fra omklædningsrum til hal er en bevægelse fra periferi til centrum. Det rummer et forløb udspændt i tid og rum, hvor aktørerne endnu har mulighed for at vende om, gå tilbage og dermed bevare deres "menneskelige « identitet.

Når aktørerne træder ind i hallen, modtages de, som kontrast til omklædningsrummets stilhed og ensomhed, af publikum brus. Råbene, klapsalverne, røgen og lyset, alle disse elementer nærmest bærer og skubber aktørerne afsted frem imod skuepladsen.

I wrestling er entreen i modsætning til eksempelvis professionel boksning forskellig fra gang til gang. Hver aktør har sin entre, wrestleren Mean Mark kommer ind til tonerne af Sex Pistols, alt imens han vredt brøler og gestikulerer ud mod publikum. Eaton og Lane fra wrestlergruppen Midnight Express kommer ind sammenbidte og cool sammen med deres manager Jim Cornett, der råber ud mod tilskuerne, samtidig med han svinger en guldglinsende tennisketsjer over hovedet. Sct. Slaughter kommer ind i hallen til rytmerne fra trommehvirvler. Foran ham går hans manager, kaldet Generalen, klædt i arabisk tøj med det irakiske flag i hænderne.

Entreen i wrestling har til formål at præsentere de forskellige aktørers roller. Gennem fagter, påklædning, ansigts- og kropsudtryk og ageren overfor publikum og kamera præsenteres vi for aktørerne som typer.
Det er som i den italienske commedia dell'arte tradition, hvor personerne gennem kostumer og ydre holdning har nøje definerede roller. Artilecchino er den lavkomiske og vulgære tjener, il Dottore fremstår som en lærd pendant, il Capitano er storpralende, men når det kommer til stykket altid en fej hund. Rollerne er alle på forhånd fastlagte. Denne klare og entydige rolleafgrænsning findes ligeledes blandt de medvirkende wrestlere.

Denne figur understreges yderligere af, at de fleste af wrestlerne bærer øgeeller om man vil kunstnernavne. Mean Mark, Million Dollar Man, Animal. Deres navne er eksplicitte tegn, der tydeligg $\varnothing r$ bestemte egenskaber og værdier. På samme tid udtrykker disse navne »overmenneskelig værdi og menneskelig intimitet ${ }^{3}{ }^{3}$ Ved denne omskrivning - tilskrivning af navnene bliver det muligt så at sige at privatisere de kæmpende. »Det lader sig herigennem gøre at anbringe ... (wrestlernes) ... privatliv på heltenes skueplads $\ll .{ }^{4}$

Citaterne stammer fra Roland Barthes Mytologier i afsnittet »Tour de France - Cykelløbet som epos«. Denne navnemytologisering er, som det ses ikke noget specielt for wrestling, men er et forhold, der karakteriserer sporten generelt. Blot er denne navnemytologisering som så mange andre ting $\mathrm{i}$ wrestling kendetegnet ved at være overbetydende - forst $\varnothing$ rret op.

De næste trin i entreen er overgangen fra gulv til ring. Her affører wrestlerne sig i nogle tilfælde dele af deres påklædning. Dog er det ikke som i anden sport således, at de kæmpende lades tilbage med stort set den samme kampdragt. Et forhold der har til for- 
mål at understrege de fælles betingelser, rammer og regler, som kampene afvikles under.

I wrestling er de kæmpende ved kampens begyndelse som oftest if $ø r t$ en eller flere feticherende rekvisitter, der definerer og afgrænser deres roller. The Million Dollar Man er under kampen iført korte sorte stramtsiddende bukser påtegnet et dollartegn. Wrestleren Animal er under seancen iført maske.

Ved ankomsten til ringen fortsætter entreen. Manageren Jim Cornett løber rundt $i$ ringen og forsøger at hidse publikum op til fordel for hans team. Sct. Slaugthers general holder en messende tale på arabisk, og går omkring i ringen med det irakiske flag, ligeledes i fors $\varnothing$ get på at hidse tilskuerne op. Andre gange sviner modstanderne gensidigt hinanden til, bistået af deres respektive managere.

Hele entreen udspilles i en potenseret atmosfære, emmende af simuleret had, vildskab og hovenhed afhængig af aktørernes på forhånd definerede roller.

I boksning er det således, at når gongong'en lyder, hilser bokserne på hinanden ved at støde handskerne sammen. Dette gentlemansritual er helt bortretoucheret fra wrestlingen. Her er det muligt, at den ene af aktørerne endnu før gongong'en har lydt, giver sin modstander, der står med ryggen til og taler med sin manager, et nakkedrag så vedkommende ryger ud af ringen.

Når wrestlerne kommer ind $i$ hallen, er kampen indirekte begyndt og akt $\varnothing$ rernes roller cementeret. Heri findes en eklatant forskel fra eksempelvis professionel boksning.

Allerede i entreen præsenteres vi for en af grundfigurerne i wrestlingen: det forstørrede, potenserede og overbetydede.

\section{Areanen- gransenedbrydningen}

"Arenakampe er ikke virkelige, de er rumligt og tidsligt afgrænsede og har spilleregler på en måde som krig og kærlighed ikke har det «. ${ }^{5}$

Arenakampe er, som det hedder i citatet fra Hans Finks artikel om arenaer, rumligt afgrænsede. Den rumlige afgrænsning i wrestling er dog flertydig. Dels er der situationen uden for ringen, inden selve kampen begynder. Dels er der den egentlige ring, der som i en boksering er indhegnet af udspændte tove. Endelig er der et areal, der løber $i$ en lige linie rundt om ringen, afgrænset af et hegn ud mod tilskuerne.

Wrestling afviger fra de fleste sportsog arenaformer ved at have udvidet arenapladsens rum eller måske nærmere sprængt det. Hensigten er at føje en ekstra dimension til kampene. Tilskuerne får gennem denne arenaudvidelse tilført en illusion om, at her er om ikke alt muligt, så dog en del mere end $\mathrm{i}$ traditionel sport. Kampene er ladet med intensitet, dramatik og nødvendighed, hvilket retfærdigg ør, at de for at kunne afvikles må have føjet et eller flere rum til.

Arenakampe er ligeledes, som det hedder i citatet, tidsligt afgrænsede. I wrestling kæmpes der som oftest, til den ene af parterne har holdt den andens skuldre nede i tre sekunder. En anden regel er, at man kan diskvalificeres, hvis man er uden for ringen i et bestemt tidsrum. Dette sker dog vist $\mathrm{i}$ 
princippet aldrig. Endelig findes der kampe, hvor et givet tidsforløb på forhånd er aftalt. Men som hovedregel adskiller wrestling sig fra anden sport ved ikke på forhånd (uden tilskuernes vidende) at være tidsligt afgrænsede.

Denne mangel på tidslig afgrænsning har, ligesom det er tilfældet med den rumlige udvidelse, til hensigt at udvide kampene og vægte dem med intensitet, alvor og drama. I wrestling prætenderes, at der som i Roms Colosseum kæmpes på liv og død, indtil den endelige vinder er fundet.

"Ved at være et sted, hvor der er draget en grænse om begivenheder, der i en vis forstand er virkelige, er arenaen med til at sætte en kontrast, der overhovedet $g \varnothing \mathrm{r}$ det meningsfuldt at udpege andre begivenheder som virkelige «. ${ }^{6}$

To af de grundfigurer, der kendetegner moderne sport, er i wrestlingen tilsyneladende sat ud af kraft. Wrestlingen forstået som form udfordrer de vandtætte skodder, der normalt gør det muligt at skelne entydigt mellem arenaens begivenheder og hverdagslivets. I stedet forsøger wrestlingen at postulere, at alt er tilladt og kan ske. I dette fors $\emptyset \mathrm{g}$ på at agere natur forsøger wrestlingen at ligne selve livet, forstået som vedvarende strøm og proces, der umuligt lader sig fastholde, tøjle, styre og bestemme.

Dette er paradokset $\mathrm{i}$ wrestling og formodentlig en af dets stærkeste facinationskilder. Selv om der er tale om total iscenesættelse og dermed fuldkommen kultur, prøver wrestlingen at simulere natur.

\section{Kampen - nu og her}

Wrestlingkampenes længde er forskellig, men en varighed på mellem to og ti minutter synes at være det typiske. Inden det når så vidt, må de kæmpende imidlertid først udsætte sig for simulerede spark i maven, slag overalt på kroppen, skaller, affinde sig med at blive hoppet på, få hovedet banket ned i gulvet, stå model til luftture rundt i ringen samt andre »sadistiske« overgreb.

Som tilskuer er man vidne til et drama omhandlende menneskelig lidelse og smerte. Mens den ene bryder får vredet armen bag ud, og ansigtet fortrækkes i skærende smerte, smiler den anden hoverende. Lidt efter er det den andens tur. Efter at have modtaget et velekspederet spark i mellemgulvet efterfulgt af to strakte fingre i øjnene, kryber den før så hoverende bryder nu på alle fire rundt $\mathrm{i}$ ringen. Lidt efter bliver han sparket ud af ringen, udmattet og tænderskærende af smerte får han slæbt sig tilbage, men blot for at modtage en byge af spark, der resulterer $\mathrm{i}$, at han krampetrækkende vrider sig af smerte - punktet før besvimelse. Triumferende strammer i det her tilfælde Mean Mark musklerne, stikker fjæset helt ind i kameraet og griner sadistisk.

Som i det oldgræske teater, hvor personernes hensigter og følelser var forstørret op via masker, ekspliciteres menneskelig smerte og lidelse sammen med udspekuleret grusomhed og raffineret ondskab i wrestlingen, så selv de mest nærsynede rækker kan være med.

Wrestling er et anskueligt drama, der tematiserer følelsesmæssige højdepunkter i menneskelivet. Smerten, hævnen, hadet og grusomheden. Følelsestilstande hvor man helt og aldeles er i sine følelsers vold uafhængigt af fornuften, loven og andre adfærdsregulerende instanser. 
»Brydekampe er en total sum af enkelte optrin, hvoraf intet er en funktion af selve summen «.

Den fremstilling af fribrydningens væsen og egenart, som Barthes giver i sit essay om fribrydning fra bogen Mytologier, minder i mange henseender om den form for showbrydning, vi kender i dag under navnet wrestling.

En wrestlingkamp er bygget episodisk op, den består af scener, der ikke nødvendigvis følger $i$ forlængelse af hinanden. I modsætning til eksempelvis en boksekamp, der med Barthes ord udtrykker »et historisk forløb, der bygges op for øjnene af tilskuerne ${ }^{8}{ }^{8}$

Denne collageagtigt iscenesatte komposition gør, at hvert øjeblik kan mættes med intensitet og betydning. Via overdreven mimik, potenserede slagscener og smerteforestillelse lades betydningsindholdet op.

Menneskelig lidelse og smerte forstørres op i et evident sprog. Dette sker på en måde, så man som tilskuer $\varnothing$ jeblikkeligt er i stand til at forbinde smerten med dens årsag. Selve wrestlingkampene foregår $i$ et helt igennem udt $\varnothing$ mmende sprog uden nævneværdige selvmodsigelser og uklarheder.

Denne udt $ø$ mmende funktion kan udover den ovenover omtalte måde, wrestlerne prætenderer smerte på, iagttages $\mathrm{i}$ sammenhængen mellem brydernes roller (mimik, påklædning med videre) og den måde, de kæmper på. Lad os se på nogle enkelte udvalgte eksempler.

Sct. Slaughter bærer udenfor ringen solbriller, han ænser næppe publikum og i det omfang, han gør det, har han kun stiltiende arrogant foragt tilovers for det. Hans fremtoning er rolig, selvsikker og velafbalanceret. Han er som en slange tilsyneladende i dvale, men dog årvågen og parat til bid, hvis nogen skulle komme for nær.

Dette indtryk som Sct. Slaugthers entre fremkalder, viderefører han under selve kampen. Han viser sig at være en nådesløs wrestler, der sammenbidt og brutalt ordner sin modstander. Han gør lige nøjagtigt det arbejde, der skal til for at vinde kampen, derudover ikke mere. Under selve kampen ulejliger han sig ikke som så mange andre wrestlere med at hovere over sin modstander, dommeren eller publikum, og efter kampen udtrykker han heller ingen glæde over at have vundet.

Han er helt igennem følelsesløs - en dræbermaskine. Dette forhold understreges yderligere af, at han efter kampen gør honnør til Generalen - »the mission is completed «.

Et andet eksempel på dette er wrestlerne the Bushwhackers, der er et såkaldt tagteam (to wrestlere der wrestler sammen). De to junglewrestlere har næsten identisk udseende. Denne tvillingefigur understreges yderligere af, at de er if $\varnothing r t$ ens $t \varnothing j$, har samme fjogede gangart, en stiv gyngende gang, hvor armene rytmisk går $\mathrm{op} o g$ ned. Desuden er deres gestik og mimik sammenfaldende.

Udenfor ringen er de fremstillet som legesyge dyr. De klør gensidigt hinandens skaldede hovedbunde, gnubber hovederne op ad publikum og lader sig

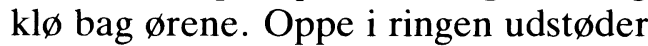
de højlydte glædesbrøl og vender det hvide ud af øjnene og gør sig skeløjede. De har krampelignende ansigtstræk, og deres opførsel leder generelt tankerne hen på noget ikke-menneskeligt.

Denne henholdsvis klovne-kæle- 
dyrsagtige og lettere debile facon overfører de til deres måde at wrestle på. Mens deres modstander står med ryggen til ringtovene og skal til at kaste sig over den ene af dem, sætter den anden, der står uden for ringen, tænderne i hans bagdel. Som et andet eksempel på dette kan nævnes et tilfælde, hvor den ene Bushwhacker lægger armen rundt om sin partners hoved, hvorefter han bruger det som en slags rambuk mod modstanderen.

Hver gang the Bushwhackers har haft held til at få modstanderen $\mathrm{i}$ gulvet, spadserer de på deres karakteristiske vuggende måde rundt $i$ ringen, alt imens de brøler ud mod publikum og vender det hvide ud af øjnene.

Via overdreven mimik og gestik, fremstilling af smerte, slag og spark med videre presses betydningsindholdet til det yderste. Stort set alt det overflødige sies fra, det der bliver tilbage er spidsbelastningspunkterne. Højdepunkterne.

»En episode er ikke en uomgængelig følge af det, der er gået forud, ej heller årsag til det, der vil følge; episoden befinder sig hinsides den kausale sammenklædning af begivenheder, som er en historie «. ${ }^{9}$

Dette citat fra Milan Kunderas roman Udødeligheden kan bruges til at beskrive wrestlingens partitur. Wrestlingens episodiske og betydningsudtømmende komposition $\mathrm{g} ø \mathrm{r}$, at forhold som proces og forløb udelukkes. I stedet betones udelukkende selve målet. Denne bevægelse kan siges at være en pointering af et ungdommeligt nu og dermed en indirekte formuleret døds- og alderdomsbenægtelse. En ekstrem fastholdelse af en nu og her situation og der- igennem et fors $\varnothing \mathrm{g}$ på at stoppe historiens gang og eliminere dens betydning.

\section{Kroppene - „Vi er fandeme til «}

I det følgende vil wrestlingens kropskultur, med udgangspunkt i Mikhail Bakhtins teorier om den groteske krop, blive fors $\emptyset \mathrm{gt}$ kommenteret og bestemt.

Ifølge Bakhtin hænger fremkomsten og udviklingen af den groteske krop sammen med overgangen fra middelalder til renæssance. Det er omtrentligt i denne fase af historien, at et individualistisk menneskesyn grundlægges. Mennesker får nu behov for at betone det, der skiller dem ud fra omverdenen, og derigennem pointere deres individualisme og selvstændighed.

Dette bevirker, at det kropslige ideal bliver en krop, der som det hedder hos Bakhtin »presents an entirely, finished, completed, strictly limited bo$\mathrm{dy} «{ }^{10}$ Individet fors $\emptyset$ ger at afgrænse sig mod dels omverdenen dels mod andre kroppe. Dette har blandt andet den konsekvens, at en række ting, der før var comme il faut, nu overgår til den privat-psykologiske sfære.

Det groteskes genstandsområde er ifølge Bakhtin de kropslige udfoldelser, der enten forbinder kroppen med omverdenen eller med andre kroppe. Gennem denne bevægelse dannes en slags dobbeltkrop. Indtagelse af føde, udskillelse af snot og sved, samleje og graviditet $»$ all these acts are performed on the confines of the body and the outer world «. ${ }^{11}$

Dette er ligeledes tilfældet med visse kropsdele såsom næsen, den åbne mund, de udspilede $\varnothing$ jne samt kønsdelene. $» .$. the grotesque body image ... 
never presents an individual body; the image consists of orifices and convexeties that present another newly conceived body ${ }^{12}{ }^{12}$

Kroppen eller dele heraf kan altså antage grotesk form ved at overskride kulturelle grænser for, hvad man kunne kalde kropslig takt og tone. I wrestling er det muligt at genfinde en række elementer af den groteske krops stil.

Hvis man ser på wrestlerparret Buschwhackers, er deres optræden krydret med groteske kropslige elementer. Deres opførsel trækker tydelige paralleller til dyreverdenen. Eksempelvis via den fælles gnubben af de skaldede hovedbunde. Eller ved, at den ene af dem lige umiddelbart inden selve kampen, slikker den andens hovedbund. Et træk der tydeligt giver associationer til hunde eller aber, der gensidigt vasker hinanden. »The combination of human and animal traits is $\ldots$ one the most ancient grotesque forms $\ll \cdot{ }^{13}$

Af andre elementer kan nævnes deres mund, der åbnes på vid gab samtidig med, at de brøler ud imod publikum. »The most important of all human features for the grotesque is the mouth $\ll .{ }^{14}$ Den åbenstående mund opløser den glatte og uigennemtrængelige overfladekrop og danner derved en anden krop. Den entydige grænse mellem de lukkede krop og verden opløses, eller mere teoretisk formuleret: skellet mellem subjekt og objekt ophører.

For en ordens skyld skal det nævnes, at den åbne mund, brølene og skrigene er gennemgående figurer i wrestlingen, om end de i særlig grad ekspliciteres i the Bushwhackers tilfælde.

»The eyes ... express an individual
... which is not essential to the grotesque. The grotesque is interested only in protruding eyes $\ll .{ }^{15}$ Som tidligere nævnt var en gentagende figur hos the Bushwhackers, at de vendte det hvide ud af $\varnothing j n e n e$ og gjorde sig skeløjede. Gennem deres »øjenoptræden « vansires billedet af øjnene som sjælens spejl, en af de mest markante udtryk for individualitet. Dette forhold ses ligeledes blandt de fleste $\emptyset$ vrige wrestlere, om end det heller ikke her er så udtalt som hos the Bushwhackers.

The Bushwhackers kamp slutter med, at den en af dem holder modstanderens skulder nede, mens dette sker, gør han sig skeløjet, laver ansigtsgrimasser og rækker tunge. Tungen er en anden grotesk figur, der ligeledes udfordrer skellet mellem overfladekrop og omverden. The Bushwhackers slutter altså deres kamp med at intensivere det groteske, herigennem slår de med tommeltykke syvtommersøm tv-kommentarens afsluttende bemærkning fast, »they are absolutely mad «.

Om disse groteske kropsfigurer, der rækker ud over sig selv og bliver til andenkrop eller om man vil merkrop, hedder det hos Bakhtin: »It is a point of transition in a life eternally renewed, the inexhaustible vessel of death and conception ${ }^{16}{ }^{16}$

Det, den groteske krop ekspliciterer, er altså forestillingen om en krop, der hele tiden dør og fødes. En cyklisk orienteret kropsopfattelse i modsætning til en lineær.

»The grotesque body is cosmic and universal $\ll .{ }^{17}$ Med dette mener Bakhtin, at den groteske krop ikke er adskilt fra eksempelvis floder, have, luften og bjergene. Den groteske krop åbner sig mod verden, ved hele tiden 
at være i konstant bevægelse. Den smelter sammen med verden istedet for at distancere og adskille sig fra den.

Nået hertil kan det, som det ligeledes blev konkluderet i kampafsnittet, siges, at wrestlerne med deres mimik, gestik og kropssprog i en række tilfælde simulerer natur. Selv om kroppene rent faktisk ofte er næsten ligeså kontrollerede og stiliserede, som det eksempelvis er tilfældet $\mathrm{i}$ bodybuilding.

Et eksempel på denne parallel til bodybuildingen er wrestleren Mr. Perfect, der er smurt ind i et fedtglinsende lag af olie, som fremhæver hans solbrændte og muskuløse krop. Som yderligere illustration til dette kan nævnes, at man i et wrestlingblad kan se en top ti over, hvem af wrestlerne, der vejer mest. ${ }^{18}$ I det selvsamme blad kan man læse en artikel om wrestleren Scott Steiner. Artiklens fotografier er alle hentet fra træningssalen, hvor Scott slider $\mathrm{i}$ det med håndvægte og forskellige muskelmaskiner. Placeret i dette maskinrum, giver han gode tips om, hvordan man bedst træner sin krop. ${ }^{19}$

Generelt kan det siges, at kroppens størrelse, veltrimmethed og ofte voldsomme muskuløsitet spiller en fremtrædende rolle $\mathrm{i}$ wrestlingen.

Det, man kan iagttage i wrestlingens »krop«, er altså sammenfattende på den ene side elementer, der er hentet fra den groteske krop og en før-moderne kropsopfattelse. På anden side elementer hentet fra en stiliseret og formgivet macho-krop - en moderne kropsopfattelse. Samlet en kropsopfattelse man kunne kalde post-modernistisk.

Dette at wrestlingen bringer kropslige elementer sammen, der tidligere var adskilte, vidner om, at modernitetens diskurs er på retur. Modernitetens krav om orden og entydighed, der eksempelvis kommer til udtryk i den moderne sport og dens betoning af den anonyme sportskrop, er forsvundet. Den anonyme overfladekrop var i moderniteten et ideal og som tidligere nævnt et middel, hvormed den enkelte kunne opnå noget andet. Men i takt med at moderniteten skrumper ind, opprioriteres kroppens form- og udtryksmæssige betydning. Kroppen bliver et mål i sig selv og et sidste område, hvormed man kan gøre opmærksom på sin eksistens. Dette skift i kropskulturen tydeliggør wrestlingen ved dens vægtning af det grotesk kropslige og de potenserede machokroppe. Med en omskrivning af digteren F. P. Jacs »jeg er fandeme til «, ${ }^{20}$ råber wrestlingkroppene os an: se os, vi er fandeme til.

\section{Stфjen for stфjens skyld}

I det følgende vil forskellige teorier af Baudrillard blive inddraget med det formål at uddybe de hidtidige analyser af wrestlingens univers, samt relatere disse til visse af Baudrillards teorier om vor nuværende kulturelle diskurs.

Efter middelalderen - renæssancen begynder der ifølge Baudrillard en opløsning af tegnforholdene i samfundet. Tegnene river sig løs fra bindinger til personer og praktiske og rituelle sammenhænge. I stedet begynder tegnene at henvise til en hensidesliggende sandhed og orden, som de foregiver at efterligne. Denne tegntilstand kalder Baudrillard et simulacre af første orden.

Med barokkens afslutning ophører ifølge Baudrillard også simulacret af 
første orden. Det er nu ikke længere muligt at se tingene gennem et perspektivistisk totalbillede.

I den anden simulacre orden henviser tegnene udelukkende til produktion. Et eksempel på dette er Marx' tanker om den uundgåelige historiske udvikling henimod det klasseløse samfund. Det er i denne periode af historien, der også kan kaldes det moderne, at begreber som for eksempel historisk proces, menneskelig frigørelse og udvikling konstitueres.

I den tredie simulacre orden bevæger vi os ifølge Baudrillard fra produktionen ind i konsumtionens æra. Denne overgang kan også formuleres som overgangen fra industri- til informationssamfund. I denne periode sætter tegnene sig fri fra de faste strukturer, de tidligere var en del af. Der er nu ikke længere nogen fast forbindelse mellem tegnet og den virkelighed, det beskriver. Tegnene kan uden videre skifte plads samtidig med, at de $»$ simulerer « tidligere tiders ordener og værdisystemer. Ifølge Baudrillard skabes der ingen nye meningshelheder, men kun blændværk - simulacre. Det »semiokratiske samfund « er en realitet.

Hvis vi overfører disse teorier til wrestlingens verden, kan wrestlingen $i$ sig selv anskues som en stor iscenesættelse - simulation. Dette er ikke blot tilfældet i kampenes minutiøst planlagte forløb, hvor slag med videre $\mathrm{i}$ vid udstrækning på forhånd er indøvede, men også i det man kunne kalde wrestlernes stil.

Wrestlernes påklædning er et eksempel på dette. Således findes der en wrestler, der udenfor ringen optræder i politiuniform med dertil hørende knippel. En anden er iført forskellige pelsstykker, der skal indikere, at han er en slags primitiv afrikansk stenaldermand. Som tidligere nævnt optræder Sct. Slaughter i fuld krigsornat, mens the Million Dollar Man er iført jakke, hvid skjorte, butterfly og "guldbælte«.

I disse eksempler ses, hvordan tegnene har løsrevet sig fra betydningssystemer, de tidligere var en uomtvistelig del af. Politiuniformen har normalt til hensigt at signalere lov og orden og myndighed, men her er den tilsyneladende bare et vilkårligt tegn løsrevet fra sin sammenhæng.

Wrestlingens indbrud $i$ andre betydningssystemer kan siges at have til hensigt at signalere støj. St $\varnothing j$ forstås her, med en af den såkaldte Birminghamskoles repræsentanter Dick Hebdiges ord, som »en mekanisme, der producerer semantisk uorden ${ }^{21}$.

Denne støjfunktion i wrestlingen kan rent metodisk sammenlignes med tendensen til st $\varnothing \mathrm{j}$ i punkstilen, der er en af Hebdiges genstandsfelter i bogen Subkultur og stil.

Det, som punkstilen gjorde og i dette her tilfælde wrestlingen gør, kan yderligere uddybes med følgende citat.

"Bag punkens udbredte »cut-ups « lå der antydninger af $\ldots$ at forvirre den kronologiske orden ved at blande detaljer fra forskellige perioder $\varkappa^{22}$ og stilarter (min tilføjelse).

Et andet eksempel til belysning af dette er den tidligere omtalte wrestler Mean Mark, der kommer ind til tonerne af The Sex Pistols, iført reminiscenser af cowboytøj. Dog er tøjets farve helt sort, hvilket leder tanken hen på noget rockeragtigt. Stilelementer fra forskellige betydningsuniverser føjes $\mathrm{i}$ en række tilfælde sammen, ikke med det formål at skabe konsistent betydning, men $i$ et fors $\emptyset \mathrm{g}$ på »at forvirre 
den kronologiske orden «-skabe støj. Om punkens brug af hagekorset hedder det i Hebdiges bog:

»Dens væsentligste værdi og appel kom netop fra denne mangel på betydning: dens mulighed for at føre bag lyset. Den blev udnyttet som en tom effekt $\ll{ }^{23}$

Endnu har der, så vidt jeg ved, ikke været anvendt hagekors i wrestling, men et element som brugen af det irakiske flag må vel i den verserende situation i Golfen kunne betragtes som noget nær samme provokation. Hvis det naturligvis ikke lige var for den sammenhæng (gadebillede - iscenesat medieshow) - symbolerne provokationerne indgik/indgår $\mathrm{i}$.

Dog kan de semantisk betragtet siges at have samme funktion, nemlig muligheden for at føre bag lyset - den tomme effekt. Begge er de eksempler på elementer pillet ud af deres traditionelle betydningssystem uden at de tilsvarende bliver forankrede i nye. Næsten rene udtryksfigurationer med kun kosmetisk indholdsværdi intakt.

Sammenfattende kan det altså siges, at der i wrestlingens univers ofte er ingen eller kun ringe forbindelse mellem tegnets indholds- og udtryksside og derfor heller ikke mellem tegnet og den virkelighed, det simulerer at beskrive.

I bogen Amerika sammenligner Baudrillard ørkenen med den amerikanske kultur. I ørkenen eksisterer ingen forskelle, der er alt lige-gyldigt. »En strålende, bevægelig og overfladisk neutralitet, der udforerer meningen og dybden, naturen og kulturen $\ll .{ }^{24}$

Denne ørken, sindbilledet på den amerikanske kultur, kan i vid udstræk- ning siges at være materialiseret $i$ showsportsdisciplinen wresting.

\section{Oplфsning af tiden og rummet}

Som nævnt tilbage i kampafsnittet udfordrer wrestlingen rummet og tiden. To centrale dimensioner der normalt afgrænser arenaen og gør det muligt at holde tingene adskilt. Denne opløsning af centrummet, af rummets afgrænsning, genfinder Baudrillard overalt i den amerikanske kultur. "Det er intet kulturelt centrum, intet center for adspredelse. Et primitivt samfund $«{ }^{25}$ I wrestlingen er scenen total, i visse af wrestlingkampene, og det er de bedste af dem, bliver endda både dommer, manager og tilskuere inddraget $\mathrm{i}$ og uden for arenaen.

Om tidens opløsning eller rettere sagt opløsningen af alt det, der ligger før og efter nuet, hedder det hos Baudrillard:

»Amerika uddriver spørgsmålet om oprindelsen, det dyrker ikke oprindelse eller mystisk ægthed, det har hverken fortid eller nogen skiftende sandhed. Fordi det ikke har kendt tidens primitive akkumulation, lever det $\mathrm{i}$ evig aktualitet ${ }^{26}$

Amerika er historie- og identitesløs, det $g ø r$ ifølge Baudrillard, at $»$ moderniteten er radikal«. Denne historieløshed kan genfindes i wrestlingkampenes episodiske opbygning. Tiden som forløb og udstrækning spiller her ingen rolle. Det, det handler om, er situationen nu og her. Hvert øjeblik er betydningsmættet, hvilket medfører, at ingen tidspunkter er mere betydende end andre. Derfor er kampen heller ikke tidsligt afgrænset, det historiske forløb og dermed den historiske forandring er sat ud af kraft. 
»Farten ... udvisker jorden og de territoriale henvisninger, da den bevæger sig op imod tidens strøm for at annullere den ... Farten er virkningens sejs over årsagen ${ }^{27}$

Et andet karakteristisk element i wrestlingen er med Baudrillards ord »farten « - det forstørrede og overdrevne. Gennem det potenseerede, forst $\varnothing r-$ rede og overdrevne presses betydningsindholdet $\mathrm{i}$ wrestlingen ustandseligt til det yderste. Gennem denne overlydsagtige bevægelse elimineres rummet og tidens betydning, og den radikale modernitet - ørkenformen skrives frem.

\section{Europa i bakspejlet}

»I Europa slæber vi en dyrkelse af forskellen efter os, derfor er vi handicappede i forhold til den radikale modernitet, som hviler på indifferencen ${ }^{28}$

Wrestling er som tidligere nævnt en ikke-entydig størrelse, men problematiserer derimod »indifferencen « ved at blande elementer af show, sport og skuespil. Den flirter med sporten, tager udgangspunkt heri og refererer hele tiden tilbage hertil. Den simulerer at være sport, men er det ikke. Tingene er ikke entydige og adskilte som i den europæiske kultur. Herved udfordres, stødes og provokeres man som europæer: hvad er det, og er det i det hele taget noget? Set i dette selvransagende perspektiv udfordrer wrestlingen vores europæiske bevidsthed og peger på forskellen mellem den amerikanske kultur, der i Baudrillards radikale udlægning er kendetegnet ved at være ørken og vores europæiske kultur og tænkning, som Baudrillard karakteriserer på denne måde:
»For os europæere, der sværmer for æstetikken og meningen ... for hvem kun det er smukt, som i dybeste forstand er moralsk og for hvem kun den heroiske skelnen mellem natur og kultur er spændende. ${ }^{29}$

Via den totale iscenesættelse udfordrer wrestling vores »normale « antagelser om, hvad sport er. Det overraskende, tilfældige, det moralske og meningsfyldte, spændingen, alle disse forhold, den europæiske sport og i nogen grad den europæiske kultur hviler på, er bortretoucheret fra wrestlingens verden. Denne totale iscenesættelse kan paralleliseres med det ontologiske, det er en barok diskurs og dermed en før-moderne figur. Lighed, frihed og broderskab, troen på udviklingen og fremskridt og fornuften, hele tanken om det moderne oplysningsprojekt, der blandt andet ekspliciteres i moderne sport er væk.

\section{Atlanterhavet skrumper ind}

»Det nye i Amerika er chokket over det første (primitive og vilde) niveau og over den tredie type af simulacrum (det absolutte simulacrum). Ikke chokket over den anden grad. En situation, der for os er vanskelig at begribe, vi, som altid har givet det andet, reflektoriske niveau fortrinsret, spaltningen, den ulykkelige bevidsthed $\ll .{ }^{30}$

For Baudrillard har det, der i hans terminologi hedder den anden simulacre, orden aldrig fået tag i Amerika. »Det sociale og filosofiske 19. århundrede nåede ikke over Atlanterhavet «. ${ }^{31}$ Som afsnittet om wrestlernes kroppe viste, ekspliciterer wrestlingen i en række tilfælde en før-moderne krop.

Denne "primitive « kropslige før-modernitet kan som figur sidestilles med wrestlingkampenes totale iscenesættel- 
se. Figurer der begge er kendetegnet ved at være hjemmehørende i barokkens univers med dens sans for det kunstlede og foreløbige.

Men, hvor barokken altid havde noget at hænge totaliteten op på, eksempelvis enevælden som guds stedlige repræsentant på jorden, der har wrestlingen ikke noget på. Den alvor, nødvendighed og de kropslige overdrivelser, som de forskellige wrestlere foregiver, er hul. Tegnene modsvarer ikke hinanden, der er ingen forbindelse imellem dem.

$»$ Her i Amerika er der ingen ideologisk spaltning, ingen mistanke, kejseren er nøgen, kendsgerningerne er tilstede $\ll .{ }^{32}$ Wrestlingen er ren form og virkning - ren støj. Den europæiske dobbeltfigur er væk. En radikal postmodernitet eller med Baudrillards ord »en radikal modernitet «.

Nået hertil kan det siges, at showsportsdisciplinen wrestling set i kulturanalytisk perspektiv på samme tid rummer en udfordring og provokation mod vor egen meningstætte, platoniserede, dualistiske og historietyngede kultur. Gennem wrestlingen formuleres »en radikal modernitet «, der dels peger tilbage mod, hvad europæisk kultur er eller måske var, dels foretager en afklædning post festum af den europæiske idræt med dens "gammeldags« dobbeltbevidsthed.

\section{Udgange - to tegn i tiden}

Sammenfattende kan det siges, at studiet af wrestling har tydeliggjort en radikal udvikling indenfor den moderne sport. En udvikling der går mod stigende iscenesættelse, stilisering og æsteticisme, og hvor kroppen ikke længere er garant for andet end sin egen væren.
Denne bevægelse kan også beskrives som en drejning væk fra et indholdsplan og over mod et udtryksplan. En udvikling henimod ørkenformen, hvor tiden og rummets betydning som »orienteringsgiver « er blevet sprængt, og hvor nuet, farten, støjen og omsætningshastighedens betydning i stedet er intensiveret.

Mere positivt begragtet kan fremskrivningen af ørkenformen også ses som en udvikling væk fra den europæiske dualisme, der som et sværd har delt vores kultur i årsag og virkning, indre og ydre, krop og sjæl, idé og virkelighed etc. En tilstand hvori det ikke længere er nødvendigt for eksempelvis sporten og kroppen at legitimere sig ved, at de hjælper historien på gled.

Denne beskrevne kropskulturelle tendens medfører dog ikke, at der kan skrives nogen altomfavnende normativ "poetik «. Således findes der indenfor kropskulturen tendenser, der stritter i andre retninger.

Eksempelvis ses en tendens til øget dyrkning af østlig og ekspressiv orienteret idræt som eksempelvis yoga, moderne ballet og forskellige orientalske kampformer. Her er det oftest den hele krop og en psykosomatisk tilgang til verden, som er udgangspunktet. ${ }^{33}$ I disse tilfælde kan kroppen bruges som et middel til at finde sig selv eller til at give udtryk for bestemte sindstilstande, ideer og forestillinger. ${ }^{34}$

I disse tilfælde bliver kroppen et middel til og et forsøg på at opnå sammenhæng og mening $i$ en sprængt verden. Herigennem ekspliciteres en forestilling om, at det gennem den enkeltes liv bliver muligt at opnå forbindelse til ægte og oprigtige værdier i tilværelsen.

Disse to polariserende tendenser i 
kulturen kan paralliseres til tyskeren Thomas Ziehe og hans teorier om den kulturelle modernisering, der har fundet sted i tiden efter 1950erne. Ifølge Ziehe har den kulturelle modernisering afstedkommet forskellige kulturelle orienteringsmønstre. Således ses en tendens til at søge det nære, der er en reaktion mod det moderne livs karakter af kulde og rationalitet. Endvidere ses en tendens til at søge det ontologiske, der er et svar på kulturens fravær af fast forankrede meninger og værdier. Disse nævnte kulturelle orienteringsfors $\emptyset \mathrm{g} k \mathrm{k}$ i nogen grad siges at være kongruente med den kropskulturelle tendens, der er blevet ridset op her sidst $\mathrm{i}$ artiklen.

Det tredie kulturelle orienterinsforsøg, som Ziehe nævner, er tendensen til potensering. Ifølge Ziehe er det udtryk for en reaktion mod tomheden. Det centrale er her tempoet, intensiteten, farten, stilen og det æstetiske. En diskurs der kan sammenfattes i ordene, "Drøn på. Lev stærkt « ${ }^{35}$ Wrestling bliver i dette vrinskende flashlight et modbillede til kulturens tomhed, som den raffineret og fantasifuldt forsøger at overdøve og overgå.

\section{Noter}

1. Neil Ferguson: Swish. Swish. p. 11, Klim 1990.

2. Med referenceløs menes, at disse idrætsaktiviteter udelukkende dyrkes for deres egen eller kroppens skyld. Jvf. Niels Kayser Nielsen: »Kroppens tabte referencer - et kropshistorisk forløb $\mathrm{i}$ : Den jyske historiker $n r$. 53. Århus 1990.

3. Roland Barthes, »Tour de France - Cykelløbet som Epos p. 56 i: Mytologier. Rhodos 1969.

4. Ibid. p. 57.

5. Hans Fink »Arenabegreber - mellem ørkensand og ørkensand«p. 9 i: Arenaer, Århus 1989.

6. Ibid. p. 7.

7. Roland Barthes, »I Fribrydningens Verden« p. 14. i: Mytologier. Rhodos 1969.

8. Ibid. p. 10.

9. Milan Kundera: Udødeligheden p. 345. Kundere refererer til definitionen fra Aristoteles' poetik. "Af alle begivenheder er, efter Aristoteles' mening episoder de værste«. Aristoteles kræver af digtningen, at det episodiske skal fjernes fra handlingen.

10. Mikhail Bachtin, Rabelais and his world. p. 322, Cambridge, Mass. og London 1969.

11. Ibid. p. 317.

12. Ibid. p. 315.

13. Ibid. p. 316.

14. Ibid. p. 317.

15. Ibid. p. 316 .

16. Ibid. p. 318.

17. Ibid. p. 318.

18. Superstar Wrestlers nr. 40, p. 12. Cosmis world group, New York 1990.

19. Ibid p. 19.

20. F. P. Jac: Jeg er fandeme til, Borgen 1979.

21. Birmingham-skolen har især beskæftiget sig med teorier omkring ungdoms- og subkulturer. Citatet stammer fra Dick Hebdige, Subkultur og stil. p. 111. Sjakalen, Århus 1983.

22. Ibid. p. 97.

23. Ibid. p. 106.

24. Jean Baudrillard, Amerika. Akademisk Forlag 1987.

25. Ibid. p. 127

26. Ibid. p. 80 .

27. Ibid. p. 14.

28. Ibid. p. 100 .

29. Ibid. p. 126 .

30. Ibid. p. 107.

31. Ibid. p. 93. 
32. Ibid. p. 89.

33. Lone Toft Christensen: »Make it burn kvindelige og mandlige kvaliteter i 80ernes kropskultur « i: Den tredie skønhed, Århus 1989. Lone Toft Christensen skelner mellem to tidstypiske kropsretninger. Henholdsvis det »stærke« kropsideal eksempel-

\section{Litteratur}

Andersen, Michael (red.): Splinter af dansk idraet. Odense 1988.

Bakhtin Mikhail: „The Grotesque Image of the Body and its Sources« i: Rabelais and his World. Cambridge Mass. og London 1968.

Barthes Roland: Mytologier. Rhodos 1969.

Baudrillard Jean: Amerika. Akademisk Forlag 1987.

Christensen Lone Toft: »Make it burn - kvindelige og mandlige kvaliteter i 80ernes kropskulturer « i: Den tredie skønhed, red. Linda Andersen, Århus 1989.

Fergusson, Neil: Swish. Swish. Klim 1990.

Red.: Fink Hans: Arenaer - om politik og iscenesattelse. Århus Universitetsforlag 1989.

Gebauer, Gunter og Gert Hortleder (red.): Sport-Eros-Tod. Frankfurt am Main 1986. vis aerobic og body-building samt det »svage « kropsideal, som der her er refereret til.

34. Jvf. Niels Kayser Nielsen: »Kroppens tabte referencer $\ll$.

35. Thomas Ziehe: Ambivalens og mangfoldighed, p. 20. Århus 1989.
Hebdige, Dick: Subkultur og stil. Sjakalen 1983.

Kayser, Nielsen Niels: »Kroppens tabte referencer - et kropshistorisk forløb « i: Den jyske historiker 53. Århus 1990.

Korsgaard, Ove: Kampen om kroppen, Gyldendal 1982.

Kundera, Milan: Udødeligheden, Gyldendal 1990.

Skude, Flemming: Den danske debat om postmodernisme. BSA-arkitektur, Kby. 1985.

Lyotard, Jean François: Det postmoderne forklaret for børn. Akademisk Forlag 1987.

Ziehe, Thomas: Ambivalens og mangfoldighed, Århus 1989. 